Journal of

Arid

ELSEVIER

\title{
Impacts of interrelated biotic and abiotic processes during the past 125000 years of landscape evolution in the Northern Mojave Desert, Nevada, USA
}

\author{
D.S. Shafer ${ }^{\mathrm{a}, *}$, M.H. Young ${ }^{\mathrm{a}}$, S.F. Zitzer ${ }^{\mathrm{a}}$, \\ T.G. Caldwell ${ }^{\mathrm{b}}$, E.V. McDonald ${ }^{\mathrm{b}}$ \\ ${ }^{a}$ Desert Research Institute, 755 E. Flamingo Road, Las Vegas, NV 89119-7363, USA \\ ${ }^{\mathrm{b}}$ Desert Research Institute, 2215 Raggio Parkway, Reno, NV 89512-1095, USA
}

Received 22 October 2005; received in revised form 21 September 2006; accepted 30 November 2006 Available online 5 February 2007

\begin{abstract}
Interrelated, biotic (flora and fauna) and abiotic (pedogenesis and hydrology) processes were examined at four sites (30, and approximately 1000-3000, 7000-12000, and 125000 years before present) in the northern Mojave Desert. Data collected at each included floral and faunal surveys; soil texture, structure, and morphology; and soil hydraulic properties. Separate measurements were made in shrub undercanopy and intercanopy microsites. At all sites, shrubs made up greater than 86 percent of total perennial cover, being least on the youngest site (4 percent) and most on the 7000-12 000-year-old site (31 percent). In the intercanopy, winter annual density was highest on the 1000 - to 3000 -year-old site $\left(249\right.$ plants $\left./ \mathrm{m}^{2}\right)$ and lowest on the oldest site $\left(4\right.$ plants $/ \mathrm{m}^{2}$ ). Faunal activity, measured by burrow density, was highest on the 1000-3000- and 7000-12000-year-old sites $\left(0.21\right.$ burrows $\left./ \mathrm{m}^{2}\right)$ and density was twice as high in the undercanopy versus the intercanopy. Burrow density was lower at the two oldest sites, although density was not statistically greater in the undercanopy than intercanopy. At the older sites, the soil water balance was increasingly controlled by Av horizons in intercanopy soils in which saturated hydraulic conductivity $\left(K_{\text {sat }}\right)$ decreased 95 percent from the youngest to the oldest site. No significant reduction in $K_{\text {sat }}$ in undercanopy soils was observed. Decreases in the intercanopy sites correlated with decreases in annual plant density and bioturbation, suggesting these processes are interrelated with surface age.
\end{abstract}

(C) 2007 Elsevier Ltd. All rights reserved.

Keywords: Aeolian; Bioturbation; Ecohydrology; Hydraulic conductivity; Mojave Desert

\footnotetext{
*Corresponding author. Tel.: + 17028625564 ; fax: + 17028625427.

E-mail address: david.shafer@dri.edu (D.S. Shafer).
} 


\section{Introduction}

Complex interactions between physical, chemical, and biological processes occur in most ecosystems. In arid ecosystems, accumulation of nutrients in upper soil horizons is due to interactions between plant primary productivity, soil erosion and deposition (including aeolian), and heterotrophic organisms influencing spatial and temporal dispersal, accumulation, and decomposition patterns of most community resources (Schlesinger et al., 1996). Differential rates and combinations of these interactions contribute to the development of a well-documented feature in many arid ecosystems commonly referred to as "fertile islands" in the canopies of major shrubs. Rostagno (1989) reported that moisture content is higher in these islands because of higher infiltration rates, and Garner and Steinberger (1989) reported that nutrients are concentrated in these areas as well. Studies in mesic environments tend to conclude that the biotic processes of plants have the dominant role in "conditioning" the soil by controlling dispersal and accumulation of plant nutrients. In contrast, during early landscape development in arid and semi-arid regions, pedogenic and abiotic processes have a greater influence on water availability, the dominant resource controlling annual net primary productivity (Hamerlynck et al., 2002).

After 5000-10 000 years, arid landscape evolution tends to be increasingly influenced by physical processes (McDonald et al., 2003). For example, aeolian dust deposition constitutes much of the pedogenic material in Pleistocene and Holocene soils of the Mojave Desert and other arid regions of the world (Reheis et al., 1995). Incorporation of this dust into near surface soil horizons provides much of the water-holding capacity of aridic soils (e.g., McDonald et al., 1996; McFadden et al., 1998).

Interactions of physical and biological processes are often studied over short time intervals which may be inadequate for explaining long-term trends in how resources are distributed in ecosystems. For example, studies at the Mojave National Preserve in California found significant deposition of fine particles by aeolian transport on relatively young surfaces ranging from 500 to 1000 years old (McDonald et al., 2003). The fine particles can reduce infiltration rates, or depth of water percolation, but they also promote bioturbation, which can create macropores that at least locally increases infiltration capacity. Interactions of these and other sometimes seemingly incongruent processes are not well understood because the data on ecosystem-wide responses are generally unavailable or are available for soil surfaces of a single or limited age range. The overarching goal of this research is to understand the long-term dynamics of coupled biotic and abiotic processes to more accurately predict future rates and directions of landscape evolution. In this study, pedogenic, hydraulic, biotic, and abiotic processes at four Mojave Desert communities spanning approximately 125000 years were measured to develop hypotheses of landscape change. We sought to answer several hypotheses, including whether: (1) pedologic development of soils with time will significantly alter soil layering and structure; (2) age dependency of saturated hydraulic conductivity is affected by the proximity to shrubs; (3) floral and faunal activities are inversely correlated to soil surface age; and (4) there are linkages between biotic and abiotic processes through time.

\section{Study area}

The study was conducted in Yucca Flat at the US Department of Energy Nevada Test Site (NTS), 105 kilometers $(\mathrm{km})$ northwest of Las Vegas, Nevada. The NTS is in 
a transition zone between the Mojave and Great Basin Deserts (Beatley, 1975; Rickard and Beatley, 1965) and encompasses $3561 \mathrm{~km}^{2}$ of the Basin and Range physiographic province (Fig. 1). Elevation ranges from 1067 meters (m) on basin floors to $2285 \mathrm{~m}$ on Rainier Mesa on the northern end of the site. Yucca Flat is a structurally closed basin in the northeast quadrant of the NTS, encompassing an area of about $780 \mathrm{~km}^{2}$. The Mojave Desert is the most arid ecosystem in North America and has the most extreme annual variation for precipitation, including decade-long variations in precipitation in the last 100 years (Hereford et al., 2004). Based on US National Oceanic and Atmospheric Administration (NOAA) weather stations, yearly precipitation at Station BJY (elevation $1241 \mathrm{~m}$ ) on the north end of Yucca Flat averages $163 \mathrm{~mm}$, and ranges from $38 \mathrm{~mm}$ in 2002 to $373 \mathrm{~mm}$ in 1998, using a 1960-2006 record (http://www.sord.nv.doe.gov/home_climate_MEDA.htm). Several above-average events (350, 277, and $373 \mathrm{~mm}$ in 1982, 1983, and 1998, respectively) were associated with El Niño events (Beck and Glancy, 2001). On average, about 62.3 percent of annual precipitation at BJY occurs between October and March, and 16.9 percent in July and August.

\section{Material and methods}

\subsection{Site selection}

Site selection criteria included (Shafer et al., 2004): (1) low surface gradients, eliminating the need to consider such processes as sheet wash; (2) lack of recent or ongoing alluvial or colluvial deposition or erosion; (3) anthropomorphic disturbance that was minimal or, if present, whose effects could be clearly distinguished from those caused by natural processes; and (4) means of estimating or establishing when the surface or landform was formed, or when significant alluvial and colluvial processes ceased.

Site 1 (Universal Transverse Mercator [UTM] Coordinates 0589957E, 4102536N, elevation $1274 \mathrm{~m}$ ) is a man-made, cut-and-fill equipment storage surface constructed and used in 1971 and 1972 (Fig. 2). The area was graded flat using material from a nearby alluvial borrow pit. A thin, pea-gravel cover (approximately $0.64 \mathrm{~cm}$ thick) was placed on the surface to help stabilize it if it became wet. The site was abandoned in 1973. Although man-made, because of the age control available, the site was selected to study how a surface on which alluvial or colluvial processes recently ceased might evolve in the earliest years following formation. Successful natural recruitment and establishment of native annuals and perennial species had occurred since 1973, including Ephedra nevadensis, Chrysothamnus nauseosus, C. viscidiflorus, Atriplex confertifolia, Hymenochlea salsola, and Lepidium fremontii. Although no differential compaction features (e.g., well-established tire tracks) are present today, Site 1 likely experienced some compaction during construction, a factor known to potentially slow recovery times of vegetation of humandisturbed sites in the Mojave Desert (Webb, 2002; Webb et al., 1988).

Site 2 (UTM Coordinates 0589812E, 4100805N, elevation $1261 \mathrm{~m}$ ) is an alluvial/distal fan surface on the east side of Yucca Flat (Fig. 2). Although shallow, intermittent channels bound the area, the presence of mature Yucca brevifolia trees indicate that alluvial or colluvial processes are no longer occurring. Dominant native perennial shrubs included A. canescens, E. nevadensis, Lycium andersonii, $H$. salsola, A. confertifolia, Grayia spinosa, and Krascheninnikovia lanata. Achnatherum hymenoides, a perennial grass, also had a high density. No direct age dates are available for Site 2. However, geomorphic and soil 


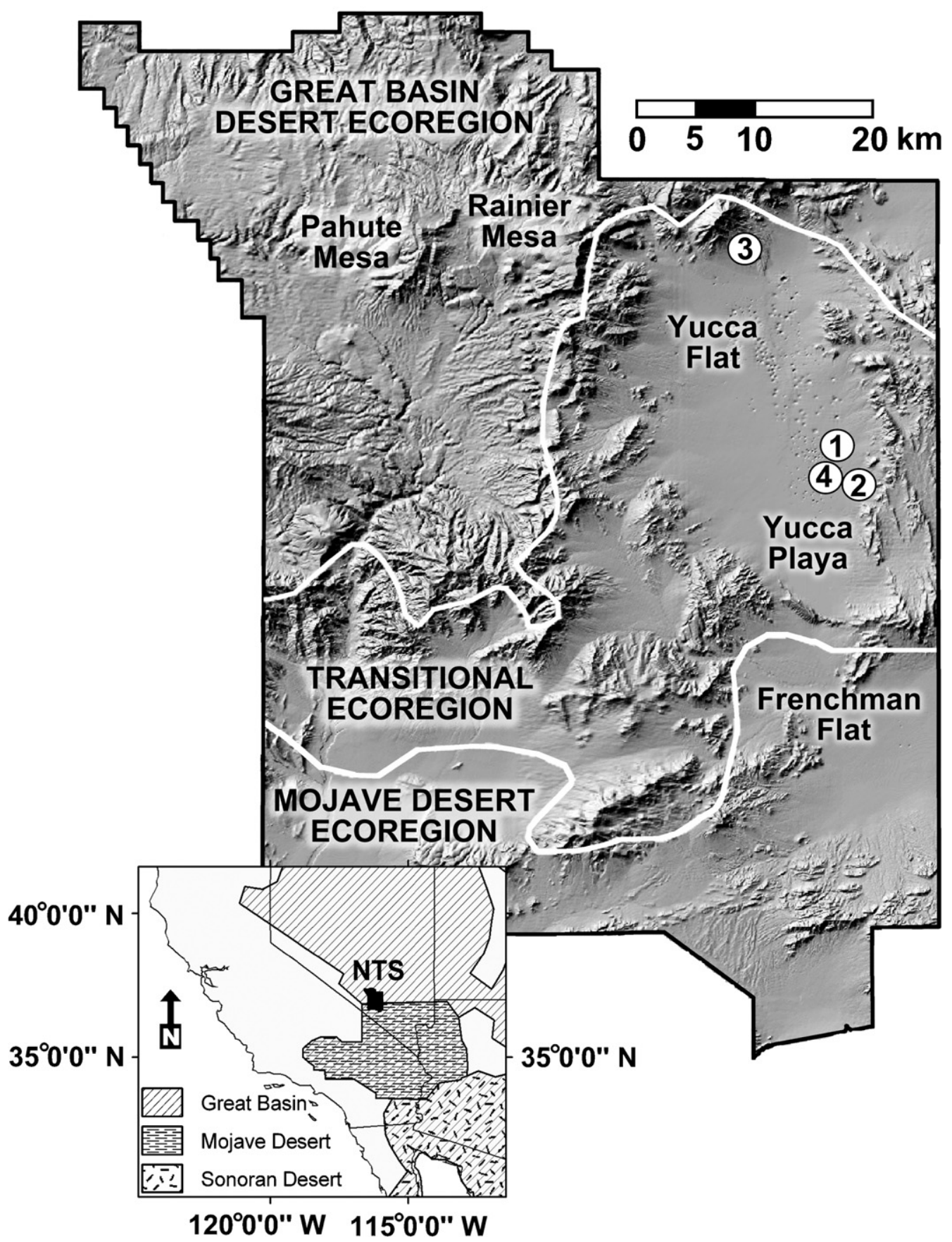

Fig. 1. The Nevada Test Site (NTS), $105 \mathrm{~km}$ northwest of Las Vegas, Nevada. Sites 1, 2, and 4 are on the east site of Yucca Flat, while Site 3 is on the north end of the basin. The sites are located in a transition zone between the Mojave and Great Basin Desert ecoregions. Ecoregion boundaries are based on Rickard and Beatley (1965) and Beatley (1975). Inset map modified from MacMahon (1985). 

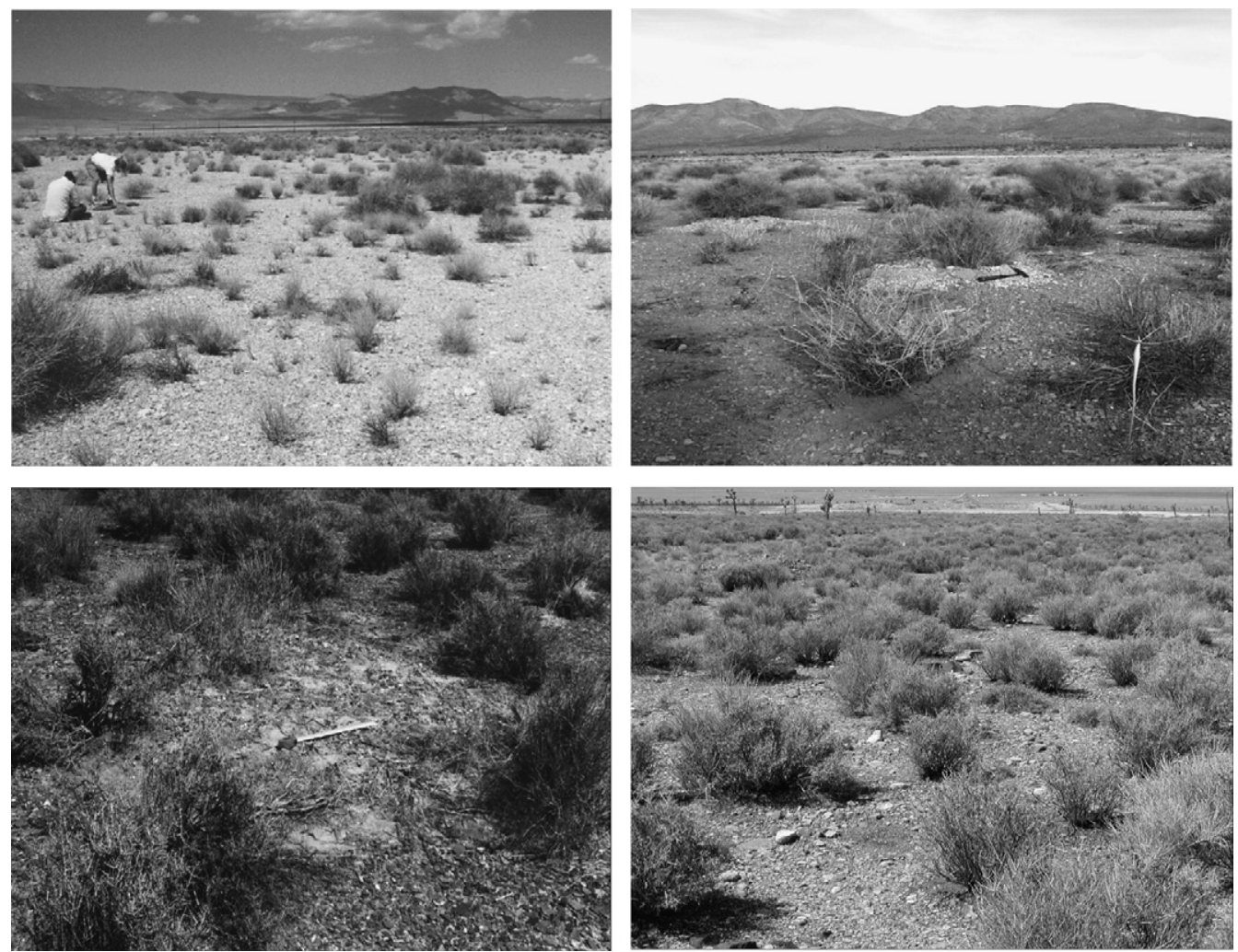

Fig. 2. Vegetation at four surfaces of different age in the northern Mojave Desert. Clockwise from the upper left are Sites 1-4 from youngest to oldest. Shrub mounds appear as light-colored soils around dominant perennial shrubs at Site 2 (rock hammer for scale).

morphology criteria suggest the surface is late Holocene in age, approximately 1000-3000 years old (Swadley and Hoover, 1990). Criteria include its low position vertically above active alluvial channels, the lack of abandoned alluvial channels on the surface, the preservation of broad bar-and-swale topography, incipient desert pavement development over small areas, the lack of surface varnish or rubification on clasts, and only weakly developed B and C soil structure (McDonald et al., 2003; McFadden et al., 1998).

Site 3 (UTM Coordinates 0583694E, 4118912N, elevation $1463 \mathrm{~m}$ ) is on the north end of Yucca Flat. The site is on an inactive alluvial/colluvial fan lobe overlying a paleosol, which extends south from Rainier Mesa (Fig. 2). A minimum age for the site surface is provided by a distinct assemblage of cultural resource artifacts on the surface that are evidence of a temporary Native American camp in the early Holocene or late Pleistocene (Jones, 2002). The Silver Lake projectile point, where found elsewhere in the southern Great Basin and northern Mojave, has been dated between 7000 and 12000 (Warren and Crabtree, 1986) and 7500 and 11200 years before present (yr BP) (Grayson, 1993). The presence of such tools and related types has been used to date terraces formed in the last high stand of pluvial lakes in the region between 8700 and $11400 \mathrm{yr}$ BP (Grayson, 1993). Desert varnish on obsidian flakes at Site 3 is evidence that the archeological material has remained intact 
and not transported to the area or recently disturbed. One factor potentially unique to Site 3 is a higher annual precipitation than the other sites. While the range in elevation is only $41 \mathrm{~m}$ between Sites 1, 2, and 4, Site 3 is $202 \mathrm{~m}$ higher than Site 2. If meteorological station BJY is considered representative of Sites 1, 2, and 4, and if precipitation increases linearly between BJY and the Rainier Mesa station, average annual precipitation at Site 3 might be $32 \mathrm{~mm}$ greater than the other sites.

Site 4 (UTM Coordinates 0589811E, 4102659 N, elevation $1302 \mathrm{~m}$ ) is an early to midPleistocene surface located immediately southwest of Site 1 (Fig. 2). Site 4 meets criteria for a mid-Pleistocene surface with a minimum age of 125000 years (Swadley and Hoover, 1990) including desert pavement expressed over the entire area, well-developed clast varnish, the burial of many smaller clasts in an aeolian mantle, and the inclusion of the site as part of a widespread surface of coalesced fans on the east side of Yucca Flat only occasionally bisected by drainages. Perennial vegetation is co-dominated by C. ramosissima and E. nevadensis, similar to Site 3, although total cover is lower. Coleogyne ramosissima is a dominant component of vegetation on stable landforms with welldeveloped soils in the region (West, 1983).

\subsection{Flora and fauna}

Belt transects $(10 \times 50 \mathrm{~m})$ were established at each site in March 2003. One longitudinal half of each transect was divided into five $(5 \times 10 \mathrm{~m})$ subplots and all perennial plants had their rectangular coordinates and canopy heights and widths measured to the nearest centimeter (Zitzer et al., 2004). Between November 2002 and February 2003, rainfall totaled $38 \mathrm{~mm}$; consequently, all perennial species, if alive, had broken bud and produced some vegetative growth prior to the start of the first survey. Live or dead status was recorded, but the time of death for an individual plant could not be determined and species identities for about 5 percent of the dead plants could not be made. Plant nomenclature is based on the Jepson Manual (Hickman, 1993) and vegetation classification for the NTS (Ostler et al., 2000).

Winter annual plant diversities and densities were measured in five paired subplots $(0.5 \times 0.5 \mathrm{~m})$ located in the adjacent half of the $10 \times 50 \mathrm{~m}$ transects. Paired sites were selected either in the undercanopy of dominant shrubs or at least $0.5 \mathrm{~m}$ from the nearest shrub canopy in the intercanopy environment. To ensure identification at the species level, winter annual surveys were conducted in mid-May when all individuals were flowering.

A literature review was conducted to determine possible burrowing vertebrate and invertebrate species found in this part of the NTS, their burrowing habits, and phenomena that would restrict the depth and distribution of their burrows. At Sites 1-3, the depth of active burrowing and of krotovina (older, soil-filled burrows) beneath dominant perennial shrubs and in intercanopy areas was measured in soil trenches. The frequency of burrows, their diameters, and location in undercanopy or intercanopy areas were measured during vegetation surveys.

For both flora and fauna survey results, analysis of variance analysis (ANOVA) was conducted to determine whether differences between sites, and between intercanopy and undercanopy microsites at the same site and between sites, were statistically significant. ANOVA statistical differences were based on the $\alpha=0.05$ level and the probability of significant difference was calculated using software by Statistical Analysis System ${ }^{\circledR}$ (SAS, 2005). 


\subsection{Soil morphology}

Soils were described from trenches excavated at Sites 1-3, to a depth at which all soil horizons and the depth of maximum fine rooting were exposed. Soil characteristics were described using US Department of Agriculture (US Department of Agriculture (USDA), 1999) standards and soil geomorphic methods of Birkeland (1999). Shrub undercanopy and intercanopy profiles were described at each site. Soil samples from each horizon were analyzed at the Desert Research Institute's Soil Characterization and Quaternary Pedology Laboratory for particle-size distribution using laser light scattering (Gee and Or, 2002), carbonate content using Chittick apparatus (Dreimanis, 1962; Machette, 1985), and electrical conductivity (Rhoades, 1996). Particle-size distribution of the less-than2-mm fraction was determined as a volume percent of each major fraction (sand, silt, and clay).

\subsection{Soil hydraulic properties}

The tension infiltrometer (TI) method (Ankeny et al., 1988; Reynolds and Elrick, 1991) was used to determine the hydraulic properties of the surface soil. Two paired undercanopy and intercanopy locations were identified at each site in undisturbed areas adjacent to the flora transects. Sites were chosen based on: (1) whether the paired locations were representative of the surveyed area, and (2) visual observation that the undercanopy and intercanopy areas were large enough to support triplicate measurements with a 20 -cmdiameter disk. Undercanopy and intercanopy locations were typically separated by $1-2 \mathrm{~m}$. Efforts were made to keep the measurement locations as close as possible, but without causing overlap of the wetting front. Disks were usually placed $50 \mathrm{~cm}$ apart. Measurements were taken by first lightly clearing away surface debris and stones in the intercanopy, and duff from the undercanopy area, following procedures in Casey and Derby (2002) and Young et al. (2004). Four to five tension steps were used for each test, typically at levels$12,9,6,3$, and 0 (saturation) $\mathrm{cm}$. Soil samples were then analyzed for particle-size distribution as described above.

Hydraulic properties were obtained through numerical inversion of the cumulative infiltration data $\left(\mathrm{mL} \mathrm{s}^{-1}\right)$ and known changes of boundary conditions using HYDRUS-2D (Simunek et al., 1996). This axisymmetric, finite-element code was used to iteratively optimize parameters found in the van Genuchten (1980) form of the soil water retention curve, and in the hydraulic conductivity equation derived by Mualem (1976) and modified by van Genuchten (1980). The retention curve has the form

$$
\theta_{\mathrm{e}}(h)=\frac{\theta(h)-\theta_{\mathrm{r}}}{\theta_{\mathrm{s}}-\theta_{\mathrm{r}}}=\frac{1}{\left(1+|\alpha h|^{n}\right)^{m}} \quad h<0
$$

and the unsaturated hydraulic conductivity function is defined as a function of $\theta$

$$
K(\theta)=K_{\text {sat }} \theta_{\mathrm{e}}^{1 / 2}\left[1-\left(1-\theta_{\mathrm{e}}^{1 / m}\right)^{m}\right]^{2} \quad h<0
$$

where $\theta_{\mathrm{e}}$ is the effective volumetric water content, $\theta_{\mathrm{s}}$ is the saturated volumetric water content, $\theta_{\mathrm{r}}$ is the residual water content as $h \rightarrow-\infty, n$ and $m$ are empirical parameters, where $m=1-1 / n, K_{\text {sat }}$ is the saturated conductivity; and $\alpha\left(\mathrm{cm}^{-1}\right)$ is an empirical fitting parameter similar, though not equal, to the inverse air entry value. Parameters were obtained using a Levenburg-Marquardt optimization procedure that minimizes 
differences between measured responses in the field (e.g., cumulative flux) versus those predicted using the model. Saturated hydraulic conductivity was then compared to site age using simple linear regression to evaluate potential soil-age correlation.

\section{Results}

\subsection{Flora}

Within plant growth form, shrubs constituted 86 percent or more of total perennial cover at all sites, with 13 shrub species out of a total perennial diversity of 21 species summed for all sites. Mean percent live perennial cover was significantly different across all sites (Table 1), lowest (4 percent) at Site 1 and highest (31 percent) at Site 3. Perennial plant densities were not correlated with live cover values because live cover, a function of density, canopy area, and percent mortality, varied significantly between species. For example, A. hymenoides had low live cover (0.02-0.30 percent across all sites), despite high densities, because canopy area per plant was low and mortality was high. In contrast, E. nevadensis had the highest cover values for all sites except Site 2, despite low densities, because canopy areas tend to be large with low mortality.

$E$. nevadensis and A. hymenoides were the only perennials that occurred on all sites, with $E$. nevadensis dominant or co-dominant on each. Mean diversity per plot was highest (9.8 species per plot) at Site 2 and was co-dominated by Atriplex canescens ( 37 percent of total cover) and $E$. nevadensis (16 percent). Three species (K. lanata, Opuntia ramosissima, and Mirabilis pudica) were endemic at Site 2. Atriplex canescens was restricted to Site 2, except for a small population ( 0.4 percent of total cover) on Site 4. Compared to the youngest site, cover and diversity were significantly greater on Site 2 (15-4 percent and 9.8-5.1 species, respectively). While percent cover increased from Site 2 to Site 3 (15 versus 31 percent), diversity was lower (9.8 versus 4.6 species). On the oldest site (Site 4), percent cover decreased to 23 percent, while diversity increased to 7.2 species.

Total winter annual plant densities per site (Fig. 3) were determined by the relative contributions of undercanopy and intercanopy areas (Table 2). Mean total annual plant density was highest at Site $2\left(246\right.$ plants $\left./ \mathrm{m}^{2}\right)$ and more than twice as great as at Site 3 $\left(110\right.$ plants $\left./ \mathrm{m}^{2}\right)$. Density at Site $4\left(19\right.$ plants $\left./ \mathrm{m}^{2}\right)$, the oldest site, was the lowest of the four. Across all sites, 26 annual species were identified, including five non-native species. Highest total annual diversity of 20 species and mean diversity of seven species occurred in the undercanopy of Site 2.

Some annual species only occurred in one microsite. But for those that occurred in both, density was greater in the intercanopy areas in only nine of 124 instances. A high preference for undercanopy microsites was observed especially for non-native Bromus madritensis ssp. rubens and B. tectorum. In contrast, densities of native Eriogonum deflexum and Chaenactis fremontii were greater in intercanopy areas at Sites 1-3. In contrast to most native species, Bromus sp. responds preferentially to sparse, but frequent, winter precipitation (Hunter, 1991) rather than regional winter storms (Beatley, 1974), which can change the ratios of non-native to native species from year to year. Annual and perennial plant diversity patterns among sites were similar during 2003, and consequently total plant diversity had the same pattern. 
Table 1

Diversity and percent cover by native perennial plants on four surfaces of different age in the northern Mojave Desert

\begin{tabular}{|c|c|c|c|c|c|}
\hline \multirow[t]{2}{*}{ Species } & \multirow{2}{*}{$\begin{array}{l}\text { Growth } \\
\text { form }\end{array}$} & \multicolumn{4}{|c|}{ Site age (yr BP) } \\
\hline & & 30 & $1000-3000$ & $7000-12500$ & 125000 \\
\hline Achnatherum hymenoides & Grass & 0.04 & 0.30 & 0.02 & 0.05 \\
\hline Achnatherum speciosum & Grass & & 0.03 & & 0.10 \\
\hline Cover by grasses (percent of total) & & 0.70 & 2.10 & 0.01 & 0.60 \\
\hline Acamptopappus shockleyi & Shrub & & & & 0.05 \\
\hline Ambrosia dumosa & Shrub & & & & 0.94 \\
\hline Atriplex canescens & Shrub & & 5.52 & & 0.09 \\
\hline Atriplex confertifolia & Shrub & 1.28 & 1.24 & & 0.30 \\
\hline Chrysothamnus nauseosus & Shrub & 0.22 & & & \\
\hline Chrysothamnus viscidiflorus & Shrub & 0.03 & & 0.47 & 0.53 \\
\hline Coleogyne ramosissima & Shrub & 0.02 & & 21.70 & 11.93 \\
\hline Ephedra nevadensis & Shrub & 2.98 & 2.39 & 8.58 & 4.85 \\
\hline Grayia spinosa & Shrub & & 0.66 & 0.25 & 0.93 \\
\hline Hymenochlea salsola & Shrub & 0.64 & 1.59 & 0.92 & \\
\hline Krascheninnikovia lanata & Shrub & & 0.57 & & \\
\hline Lepidium fremontii & Shrub & 0.76 & & & 0.06 \\
\hline Lycium andersonii & Shrub & & 2.74 & 0.56 & 2.05 \\
\hline Cover by shrubs (percent of total) & & 97.70 & 94.20 & 99.70 & 86.00 \\
\hline Opuntia basilaris & Cactus & & & 0.08 & \\
\hline Opuntia ramosissima & Cactus & & $<0.01$ & & \\
\hline Cover by Cacti (percent of total) & & 0 & 0.10 & 0.24 & 0 \\
\hline Mirabilis pudica & Forb & & 0.25 & & \\
\hline Sphaeralcea ambigua & Forb & 0.02 & & & \\
\hline Stephanomeria pauciflora & Forb & 0.08 & & 0 & 0 \\
\hline Cover by Forbs (percent of total) & & 1.65 & 1.60 & 0 & 0 \\
\hline Yucca brevifolia & Tree & & 0.32 & 0.01 & 3.40 \\
\hline Cover by trees (percent of total) & & 0 & 2.00 & $<0.01$ & 13.40 \\
\hline $\begin{array}{l}\text { Total species richness (all } \\
\text { subplots) }\end{array}$ & & 10 & 12 & 9 & 13 \\
\hline $\begin{array}{l}* \text { Mean number of species } \\
F=17.76, \text { pr }>F<0.0001\end{array}$ & & $5.1 \pm 0.6 \mathrm{c}$ & $9.8 \pm 0.4 \mathrm{a}$ & $4.6 \pm 0.4 \mathrm{c}$ & $7.2 \pm 0.6 b$ \\
\hline $\begin{array}{l}* \text { Mean live cover } F=75.01 \\
\operatorname{pr}>F<0.0001\end{array}$ & & $4.4 \pm 3.4 \mathrm{~d}$ & $14.9 \pm 2.9 \mathrm{c}$ & $31.4 \pm 3.7 \mathrm{a}$ & $22.9 \pm 2.9 \mathrm{~b}$ \\
\hline $\begin{array}{l}* \text { Mean dead cover } F=11.57 \text {, } \\
\text { pr }>F 0.0002\end{array}$ & & $0.7 \pm 0.3 \mathrm{~b}$ & $7.9 \pm 1.9 \mathrm{a}$ & $6.5 \pm 0.9 \mathrm{a}$ & $3.0 \pm 0.2 \mathrm{~b}$ \\
\hline
\end{tabular}

*Means followed by the same letter in the same row are not significantly different $(\alpha=0.05)$.

\subsection{Fauna}

At Sites 2-4, burrows as a measure of faunal abundance were more common in undercanopy areas than in intercanopy areas (Fig. 4). Although no burrows were observed in transects at Site 1, they were observed elsewhere on the site. The shrub 


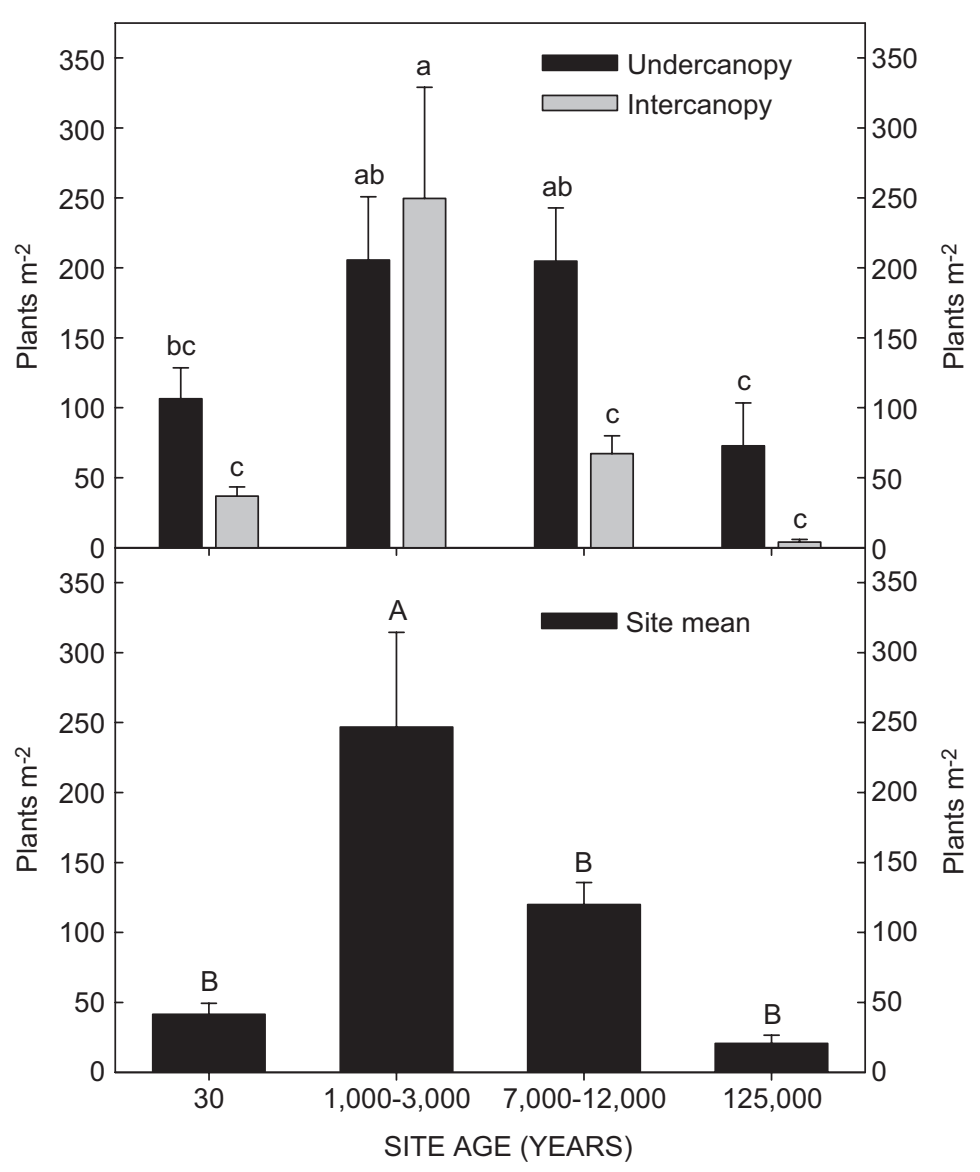

Fig. 3. Winter annual plant densities for undercanopy, intercanopy soils (above), and within site mean (below) across four surfaces of different age in the northern Mojave Desert. Bars with a letter in common are not significantly different for $\alpha=0.05$.

undercanopy-burrow linkage was most evident at Site 2, contributing to mounds with larger clasts atop finer-grained material (Fig. 2). An indication of the frequency and extent of soil turnover from bioturbation were clasts with carbonate rinds occurring on the surface. These rinds form in the subsurface, and are usually eroded or dissolved away if exposed for a significant length of time (McFadden et al., 1998). In general, the maximum depth of active burrows and krotovina coincided with the depth of larger roots, but not as deep as finer roots. Burrows and krotovina were observed to a depth of $65 \mathrm{~cm}$ at Site 1, $43 \mathrm{~cm}$ at Site 2, and $30 \mathrm{~cm}$ at Site 3. In comparison, the maximum root depth was greatest at Site $1(238 \mathrm{~cm})$, and shallower at Sites 2 and $3(118$ and $75 \mathrm{~cm}$, respectively).

Total animal burrow density was similar on Site $2\left(0.22 / \mathrm{m}^{2}\right)$ and Site $3\left(0.24 / \mathrm{m}^{2}\right)$ (see Fig. 4). However, significant differences were observed in the microsite distribution of burrows at these sites. The number of intercanopy burrows was 50 percent greater on Site 3 than on Site 2, while the similarity in the overall density was the result of 100 percent increase in perennial cover at Site 3 compared to Site 2 (31 versus 15 percent). No burrows were recorded in the transect at Site 1 and density on Site $4\left(0.02 / \mathrm{m}^{2}\right)$ was significantly less 
Table 2

Winter annual diversity and density (plants $\mathrm{m}^{-2}$ ) on four surfaces of different age in the northern Mojave Desert

\begin{tabular}{|c|c|c|c|c|c|c|c|c|}
\hline & \multicolumn{8}{|c|}{ Site age (yr BP) } \\
\hline & \multicolumn{2}{|l|}{30} & \multicolumn{2}{|c|}{$1000-3000$} & \multicolumn{2}{|c|}{$7000-12500$} & \multicolumn{2}{|c|}{125000} \\
\hline & Inter & Under & Inter & Under & Inter & Under & Inter & Under \\
\hline \multicolumn{9}{|l|}{ Non-native species } \\
\hline Bromus madritensis & 1.6 & 52.0 & 6.4 & 79.2 & 5.6 & 172.0 & & 24.0 \\
\hline Bromus tectorum & & 5.6 & 1.6 & 7.2 & & 0.8 & & 2.4 \\
\hline Erodium cicutarium & & & 0.8 & 3.2 & & 0.8 & & \\
\hline Halogetom glomeratus & 0.8 & & & & & & & \\
\hline Salsola tragus & 0.8 & 2.4 & 0.8 & & & & & \\
\hline \multicolumn{9}{|l|}{ Native species } \\
\hline Amsinkia tessellata & & & & & 0.8 & & & \\
\hline Camissonia boothii & & & 0.8 & & & & & 10.4 \\
\hline Chaenactis fremontii & 9.6 & & 171.2 & 86.4 & 0.8 & & 1.6 & 2.4 \\
\hline Chorizanthe rigida & & 0.8 & & & & & 1.6 & \\
\hline Cryptantha circumscissa & & & & 0.8 & & & & \\
\hline Cryptantha micromera & & & 9.6 & 0.8 & 1.6 & & & 4.0 \\
\hline Cryptantha nevadensis & & & 0.8 & 8.0 & & & & 4.8 \\
\hline Cryptantha utahensis & & & & 1.6 & & & & \\
\hline Descurainia pinnata & & 6.4 & & & & & & \\
\hline Eriogonum deflexum & 8.0 & & 29.6 & 4.8 & & & & \\
\hline Eriogonum trichopes & & & 13.6 & & & & & 0.8 \\
\hline Eriophyllum pringlei & 4.0 & 26.4 & 0.8 & & 53.6 & 16.0 & & \\
\hline Eschscholzia glyptosperma & & & & & & 0.8 & & \\
\hline Gilia inconspicua & 1.6 & & 0.8 & & & & & \\
\hline Glyptopleura marginata & & & 3.2 & & & & & \\
\hline Ipomopsis polycladon & & & & & 0.8 & & & 0.8 \\
\hline Langlossia setosissima & & & 4.0 & & & & & \\
\hline Lepidium lasiocarpum & & 1.6 & 3.2 & & & & & \\
\hline Mentzelia albicaulis & 2.4 & 9.6 & 0.8 & 4.8 & 1.6 & 10.4 & & 2.4 \\
\hline Nama demissum & 0.8 & & & & & & & \\
\hline Oxytheca perfoliata & & & & & 0.8 & & & 0.8 \\
\hline Pectocarya platycarpa & 0.8 & & 1.6 & & & & & \\
\hline
\end{tabular}


Site age (yr BP)

\begin{tabular}{|c|c|c|c|c|c|c|c|}
\hline \multicolumn{2}{|l|}{30} & \multicolumn{2}{|l|}{$1000-3000$} & \multicolumn{2}{|l|}{$7000-12500$} & \multicolumn{2}{|l|}{125000} \\
\hline Inter & Under & Inter & Under & Inter & Under & Inter & Under \\
\hline \multirow{2}{*}{6.4} & 1.6 & & 0.8 & 0.8 & & 0.8 & $\begin{array}{r}3.2 \\
14.4\end{array}$ \\
\hline & & & & 0.8 & 4.0 & & \\
\hline $36.8 \pm 6.6 \mathrm{c}$ & $106.4 \pm 22.1 \mathrm{bc}$ & $249.6 \pm 79.4 \mathrm{a}$ & $205.6 \pm 44.7 \mathrm{ab}$ & $67.2 \pm 12.7 \mathrm{c}$ & $204.8 \pm 38.0 \mathrm{ab}$ & $4.0 \pm 1.8 \mathrm{c}$ & $72.8 \pm 30.6 \mathrm{c}$ \\
\hline $4.2 \pm 0.6 \mathrm{~b}$ & $3.8 \pm 0.9 \mathrm{~b}$ & $7.0 \pm 1.1 \mathrm{a}$ & $5.0 \pm 0.9 \mathrm{ab}$ & $3.2 \pm 0.4 \mathrm{~b}$ & $3.2 \pm 0.7 \mathrm{~b}$ & $0.8 \pm 0.4 \mathrm{c}$ & $5.0 \pm 1.0 \mathrm{ab}$ \\
\hline
\end{tabular}

*Means followed by the same letter in the same row are not significantly different $(\alpha=0.05)$. 


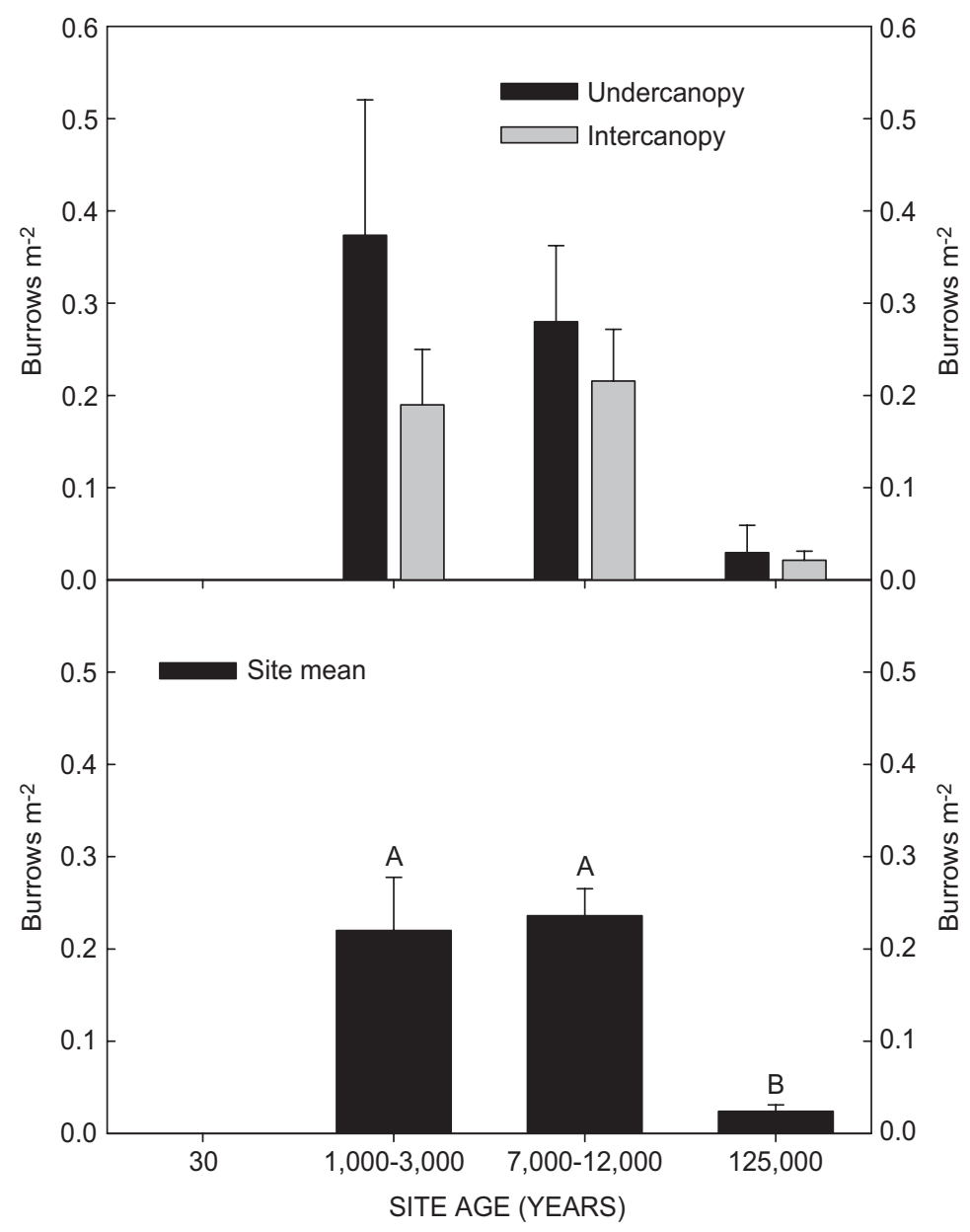

Fig. 4. Burrow densities for undercanopy, intercanopy soils (above), and within site mean (below) across four surfaces of different age in the northern Mojave Desert. Bars with a letter in common are not significantly different for $\alpha=0.05$.

than at Sites 2 and 3. However, the trend for greater burrow densities in undercanopy versus intercanopy at Sites $2-4$ was not statistically significant.

While other animals may have used previously constructed burrows, small mammals were likely responsible for the burrows observed and mapped. Important families of small, burrowing mammals on the NTS include Heteromyidae, Cricetidae, Geomyidae, and Sciuridae. Rodents commonly sampled in the transition zone of the NTS include Perognatus longimembris, Dipodomys merriami, D. ordii, D. microps, Ammonspermophilus leacurus, Lagurus curtatus, and Thomomys bottae (Green et al., 1997; Hunter and Medica, 1987). Nests of Neotoma sp. at Sites 1 and 2 contributed to some mounds beneath perennial shrubs. Larger mammals including badger (Taxidea taxus), pronghorn antelope (Antilocapra Americana), and coyote (Canis latrans) (Burt and Grossenheider, 1980) could be present periodically at any of the sites, although bioturbation related to them were not 
observed during the study period. Feral horses (Equus callabus) also occur on the NTS, although they are largely confined to the northwestern part of the site (Greger, 1995).

\subsection{Soil morphology}

At Site 1, one soil profile (No. NA3P-1) below an E. nevadensis shrub canopy had a 3-cm organic $(\mathrm{O})$ horizon consisting of a cover of poorly decomposed leaves and twigs from the overlying canopy. The uppermost mineral soil horizon was a weakly developed surface (A) horizon with weak blocky soil structure and a light accumulation of disseminated organic matter. The underlying $C$ (alluvium) horizons had no soil structure and minimal evidence of pedogenic alteration except for localized mixing due to bioturbation. The soil texture and soluble salt and carbonate content show no pedogenic modification (Table 3). Measured amounts of salt and carbonate reflected the soil used for fill material in construction of the site.

Two profiles were described at Site 2, NA3PC-1 in the intercanopy and NA3PC-2 in the shrub canopy of $A$. dumosa. The intercanopy soil had two weakly developed Av (vesicular) horizons, commonly formed in desert soils in the southwest US from long-term accumulation of aeolian fines (desert dust) below the soil surface (McFadden et al., 1998). Total silt and clay content was 31 percent in the Av horizons, but only 9 percent in the $\mathrm{C}$ horizon (Table 3). The underlying, slightly illuviated horizon (BCk1) was massive to weak, subangular blocky, and had some indication of accumulated dust as well. Pedogenic carbonate coatings on the undersides of clasts ranged from patchy to near continuous. The undercanopy profile had a 4-cm O horizon similar to that at Site 1. Also, as at the youngest site, the uppermost soil horizon was a weakly developed AC horizon with weak, blocky soil structure and a light accumulation of disseminated organic matter that formed the underlying soil mound. The BCk/Avj horizon was a mixed horizon that contained remnants of the Avj horizon (at one time at the soil surface) buried by formation of the AC horizon. Most of the horizon appeared to have been altered by bioturbation to form morphologic properties similar to a BCk horizon. The Avj remnants were massive with weak, platy structure remaining in places and could be traced laterally to the intercanopy.

Two soil profiles were also described at Site 3, one from below an E. nevadensis canopy (NA8-2), the other in the intercanopy (NA8-1). A significant paleosol was observed by the presence of a Btk2 horizon at a depth of $52 \mathrm{~cm}$. The soil in the intercanopy areas had a well-developed and thick $(10-\mathrm{cm})$ Av horizon with moderate-to-weak platy and subangular blocky structure. The location of this site at the north end of Yucca Flat and at a slightly higher elevation probably contributed to aeolian deposition at this site. The soil had a total silt and clay content of 44 percent (Table 4). The soil had two Btk horizons beneath the Av horizon. The Btk horizons had a noticeably redder soil hue relative to soils at Sites 1 and 2 ( $7.5 \mathrm{yr}$ versus $10 \mathrm{yr}$ hues), possibly because of higher annual precipitation at the site. Total silt and clay content in the Btk horizons ranged from 72 to 49 percent, with texture ranging between a clay loam to sandy clay loam. Argillans (coatings of translocated clay) were abundant in the Btk horizons as well. However, carbonate content was low (1-5 percent) and was highest in the Btk1 horizon (Table 3). In contrast to Sites 1 and 2, the undercanopy soil at Site 3 lacked a cover of poorly decomposed leaves and twigs from the overlying canopy. The uppermost soil horizon was a weakly developed AC horizon that ranged from weak, subangular blocky soil structure to structureless (single-grained) with a light accumulation of disseminated organic matter. The $\mathrm{AC}$ and underlying $\mathrm{C}$ horizon 
Table 3

Summary of measured soil properties at four surfaces of different age in the northern Mojave Desert

\begin{tabular}{|c|c|c|c|c|c|c|c|c|c|}
\hline Horizon & Depth $(\mathrm{cm})$ & $\begin{array}{l}\% \text { Gravel } \\
(\geqslant 2 \mathrm{~mm})^{\mathrm{a}}\end{array}$ & $\begin{array}{l}\% \text { Sand } \\
(2-0.0625 \mathrm{~mm})^{\mathrm{b}}\end{array}$ & $\begin{array}{l}\% \text { Coarse silt } \\
(62.5-15 \mu \mathrm{m})^{\mathrm{b}}\end{array}$ & $\begin{array}{l}\% \text { Fine silt } \\
(15-3 \mu \mathrm{m})^{\mathrm{b}}\end{array}$ & $\begin{array}{l}\% \text { Clay } \\
(<3 \mu \mathrm{m})^{\mathrm{b}}\end{array}$ & $\begin{array}{l}\% \text { Silt }+ \text { clay } \\
(<62.5 \mu \mathrm{m})^{\mathrm{b}}\end{array}$ & $\begin{array}{l}\text { Soluble salts } \\
\left(\mathrm{g} \mathrm{kg}^{-1}\right)\end{array}$ & $\% \mathrm{CaCO}_{3}$ \\
\hline
\end{tabular}

Site 1 -30 years

Undercanopy [Soil no. NA3P-1]

O $0-3+\quad$ ND

Ac $\quad 0-10 \quad 63$

$\begin{array}{lll}\mathrm{C} 1 & 10-46 & 64\end{array}$

C2 $46-118 \quad 61$

C3 118-238 6

68

Site 2-1000-3000 years

Undercanopy [Soil no. NA3PC-2]

$\begin{array}{lllll}\text { O } & 0-4+ & \text { ND } & \text { ND } & \text { ND } \\ \text { AC } & 0-11 & 31 & 69 & 15 \\ \text { BCk/Avj } & 11-23 & 28 & 72 & 14 \\ \text { BCk1 } & 23-40 & 43 & 80 & 10 \\ \text { BCk2 } & 40-79 & 65 & 88 & 5 \\ \text { Ck1 } & 79-118 & 73 & 85 & 4\end{array}$

Intercanopy [Soil no. NA3PC-1]

$\begin{array}{lll}\text { Av1 } & 0-3 & 52 \\ \text { Av2 } & 3-8 & 37 \\ \text { Bck-1 } & 8-18 & 58 \\ \text { BCk2 } & 18-34 & 71 \\ \text { Ck1 } & 34-79 & 70 \\ \text { Ck2 } & 79-109 & \text { ND }\end{array}$

69
69
66
81
91
ND

18
15
14
9
4
ND

ND
7
10
9
4

ND
9
12
12
4

ND
24
32
32
13

$\begin{array}{ll}\text { NA } & \text { NA } \\ 2.9 & 24 \\ 1.1 & 17 \\ 1.1 & 19 \\ 2.9 & 20\end{array}$


Table 3 (continued)

\begin{tabular}{|c|c|c|c|c|c|c|c|c|c|}
\hline Horizon & Depth $(\mathrm{cm})$ & $\begin{array}{l}\% \text { Gravel } \\
(\geqslant 2 \mathrm{~mm})^{\mathrm{a}}\end{array}$ & $\begin{array}{l}\% \text { Sand } \\
(2-0.0625 \mathrm{~mm})^{\mathrm{b}}\end{array}$ & $\begin{array}{l}\% \text { Coarse silt } \\
(62.5-15 \mu \mathrm{m})^{b}\end{array}$ & $\begin{array}{l}\% \text { Fine silt } \\
(15-3 \mu \mathrm{m})^{b}\end{array}$ & $\begin{array}{l}\% \text { Clay } \\
(<3 \mu \mathrm{m})^{\mathrm{b}}\end{array}$ & $\begin{array}{l}\% \text { Silt }+ \text { clay } \\
(<62.5 \mu \mathrm{m})^{\mathrm{b}}\end{array}$ & $\begin{array}{l}\text { Soluble salts } \\
\left(\mathrm{g} \mathrm{kg}^{-1}\right)\end{array}$ & $\% \mathrm{CaCO}_{3}$ \\
\hline \multicolumn{10}{|c|}{ Site 3-7000-12500 years } \\
\hline \multicolumn{10}{|c|}{ Undercanopy [Soil no. NA8-2] } \\
\hline $\mathrm{Cl}$ & $0-6$ & 23 & 49 & 13 & 17 & 21 & 51 & 1.2 & 1 \\
\hline $\mathrm{C} 2$ & $6-17$ & 25 & 51 & 14 & 16 & 19 & 49 & 0.9 & 2 \\
\hline Av & $17-27$ & 5 & 45 & 16 & 19 & 19 & 55 & 0.9 & 1 \\
\hline Btk1 & $27-52$ & 17 & 23 & 13 & 17 & 48 & 77 & 0.9 & 3 \\
\hline Btk2 & $52-74$ & ND & ND & ND & ND & ND & ND & ND & ND \\
\hline \multicolumn{10}{|c|}{ Intercanopy [Soil no. NA8-1] } \\
\hline Av & $0-10$ & 50 & 55 & 16 & 17 & 12 & 45 & 0.2 & 1 \\
\hline Btk1 & $10-31$ & 69 & 28 & 15 & 23 & 34 & 72 & 1.1 & 5 \\
\hline Btk2 & $31-49$ & 65 & 51 & 8 & 18 & 24 & 49 & 15.1 & 1 \\
\hline
\end{tabular}

ND, not determined.

${ }^{\text {a }}$ Percent of sample $>2 \mathrm{~mm}$, the remainder being $<2 \mathrm{~mm}$ or the fine-earth fraction.

${ }^{\mathrm{b}}$ Percent of fine-earth fraction $(<2 \mathrm{~mm})$. 
Table 4

Average \pm standard deviation for textural components of material sampled at intercanopy and undercanopy areas

\begin{tabular}{|c|c|c|c|c|c|}
\hline Year & $\%$ Gravel $^{\mathrm{a}}$ & $\%$ Sand $^{\mathrm{b}}$ & $\%$ Silt $^{\mathrm{c}}$ & $\%$ Clay $^{\mathrm{d}}$ & $\%$ Fines $^{\mathrm{e}}$ \\
\hline \multicolumn{6}{|l|}{ Intercanopy } \\
\hline 30 & $49.3 \pm 5.2$ & $79.7 \pm 6.0$ & $14.5 \pm 1.9$ & $5.8 \pm 2.5$ & $20.4 \pm 6.0$ \\
\hline $1000-3000$ & $35.8 \pm 7.8$ & $80.2 \pm 3.0$ & $14.2 \pm 0.5$ & $5.7 \pm 2.4$ & $19.8 \pm 3.0$ \\
\hline $7000-12500$ & $55.6 \pm 17.7$ & $55.6 \pm 6.0$ & $28.3 \pm 2.6$ & $16.1 \pm 1.9$ & $44.4 \pm 6.0$ \\
\hline 125000 & $31.6 \pm 21.0$ & $50.6 \pm 3.9$ & $34.1 \pm 1.7$ & $15.3 \pm 3.8$ & $49.4 \pm 3.9$ \\
\hline \multicolumn{6}{|l|}{ Undercanopy } \\
\hline 30 & $38.6 \pm 7.8$ & $84.1 \pm 3.0$ & $10.9 \pm 1.1$ & $5.0 \pm 1.2$ & $15.9 \pm 3.1$ \\
\hline $1000-3000$ & $33.0 \pm 13.4$ & $80.7 \pm 2.8$ & $15.6 \pm 1.1$ & $3.7 \pm 0.8$ & $19.1 \pm 2.6$ \\
\hline $7000-12500$ & $26.4 \pm 7.9$ & $65.1 \pm 5.0$ & $23.0 \pm 1.6$ & $11.9 \pm 5.4$ & $34.9 \pm 4.9$ \\
\hline 125000 & $27.2 \pm 12.6$ & $70.4 \pm 8.0$ & $23.0 \pm 2.8$ & $6.6 \pm 2.6$ & $29.6 \pm 8.0$ \\
\hline
\end{tabular}

Gravel fraction is the weight percent of the entire sample $>2 \mathrm{~mm}$. The remaining textural analysis involves only the fine-earth fraction $(<2 \mathrm{~mm})$.

a $\%$ Gravel is representative of the total sample $>2 \mathrm{~mm}$.

$\mathrm{b}_{\%}$ Sand of the fine-earth fraction ranging from 62.5 to $2000 \mu \mathrm{m}$.

$\mathrm{c}_{\%}$ Silt of the fine-earth fraction ranging from 3 to $62.5 \mu \mathrm{m}$.

$\mathrm{d}_{\%}$ Clay of the fine-earth fraction $<2 \mu \mathrm{m}$.

${ }^{\mathrm{e}}$ Arithmetic average \pm standard deviation of all soil components $<62.5 \mu \mathrm{m}$.

formed the shrub mound built over the existing Av horizon. The buried Av had weak platy and subangular blocky structure, a silt loam texture, and a total silt and clay content of 55 percent. The Av overlay two Btk horizons similar to the intercanopy. The intercanopy at Site 3 was covered with a moderately developed desert pavement whose interlocking clasts had a dark desert varnish on exposed clast surfaces. Sorting and alignment of desert pavement clasts were better developed at Site 4, the oldest site. However, trench excavation was not authorized for Site 4 and soil descriptions were limited to near-surface characterization.

Faunal and floral bioturbation impacted the undercanopy soils at Sites 1 and 2, and to a lesser degree at Site 3. The fine texture of the AC, forming the bulk of the circular and conical mound of soil that extended slightly beyond the edge of the shrub canopy, and C horizons suggests the majority of the soil matrix is from underlying soil brought to the surface through bioturbation, although some of the material may be a result of the shrubs themselves creating surface roughness that causes wind-suspended particles to be deposited and resist resuspension (e.g., Crawley and Nickling, 2003; Gillette, 1999). Several open burrows (3-4 cm in diameter and 10-30 cm in length) were exposed in the soil trench wall. Krotovina were observed at Sites 1 and 2, evidence of past burrowing activity. Many of the shrubs also had open exit burrows (some exceeding $10 \mathrm{~cm}$ in diameter) at undercanopy soil surfaces, indicating current burrowing activity.

Comprehensive descriptions of the soil profiles are available electronically in Shafer et al. (2004) at: 〈www.osti.gov/bridge $>$.

\subsection{Soil hydraulic properties}

In total, 48 TI tests were conducted at the four sites. In a few cases, instrument failure did not allow completion of tests, reducing the number of replicates. In contrast, at some 
locations more than three measurements were made at a given intercanopy or undercanopy area. In the latter cases, the results were included in the calculation of the mean. The addition of sampling locations did not impact the results because the undercanopies and intercanopies at each site were treated as replicates.

Results of soil texture analysis showed an increase in fines (silt + clay) content for both the intercanopy and undercanopy areas, with the exception of the undercanopy of Site 4 compared to that of Site 3 (Table 4). The results are consistent with McDonald et al. (2003) and Young et al. (2004) for pavement surfaces at the Mojave National Preserve, in which increases in fines could be attributed to pedogenic development of the soil surface. Consistent with results from Caldwell et al. (2006), the sand content in the undercanopies was consistently higher than in the intercanopy areas, promoting higher infiltration.

Table 5 shows the soil hydraulic properties obtained through numerical inversion of TI data. $K_{\text {sat }}$ was log-transformed prior to averaging, to account for the log-normal distribution that conductivity is known to exhibit (Mohanty and Mousli, 2000; White and Sully, 1992). Coefficients of determination (i.e., $R^{2}$ ) from the modeling, a measure of success in the inversion routine, ranged from 0.986 to 0.999 , with an overall mean of 0.998 . The $K_{\text {sat }}$ showed a reducing trend with age in the intercanopy area ( $R^{2}$ of 0.873$)$, but not for the undercanopy sites $\left(R^{2}\right.$ of 0.002$)$. The lack of sensitivity of $K_{\text {sat }}$ in the undercanopy, and the overall higher values of $K_{\text {sat }}$, may be due to a combination of processes including bioturbation of the near-surface soils, disruptioning soil layer development, including the Av horizon; additions of fine-grained material brought out of suspension by the surface roughness created by shrubs; and the presence of larger macropores (e.g., near-surface roots and burrows) in shrub undercanopies.

In contrast, the reduction in $K_{\mathrm{sat}}$ in the intercanopy soils with age is at least partly the result of a decreased frequency of some of the same processes that maintain higher $K_{\text {sat }}$ values in the undercanopy soils. Burrows are less common and, particularly at the two older sites, the lack of successful plant recruitment reduces pathways of water into the soil. In addition, the Av horizons, whose initial development was noted at Site 2 as well as other soil horizonation, will result in reduced water entry and decreased availability of water in deeper horizons. However, this would not translate directly into higher surface runoff. The

Table 5

Results of field analyses of hydraulic properties at four surfaces of different age in the northern Mojave Desert

\begin{tabular}{|c|c|c|c|c|c|}
\hline Surface age (yr BP) & $\theta \mathrm{s}$ & $\alpha\left(\mathrm{cm}^{-1}\right)$ & $n$ & $K_{\text {sat }}\left(\mathrm{cm} \mathrm{d}^{-1}\right)$ & $R^{2}$ \\
\hline \multicolumn{6}{|l|}{ Intercanopy areas } \\
\hline 30 & 0.262 & 0.137 & 1.495 & 280.02 & 0.997 \\
\hline $1000-3000$ & 0.269 & 0.060 & 2.522 & 86.98 & 0.999 \\
\hline $7000-12500$ & 0.304 & 0.086 & 1.753 & 109.10 & 0.999 \\
\hline 125000 & 0.215 & 0.064 & 2.454 & 27.95 & 0.998 \\
\hline \multicolumn{6}{|l|}{ Undercanopy areas } \\
\hline 30 & 0.318 & 0.204 & 1.378 & 392.74 & 0.997 \\
\hline $1000-3000$ & 0.397 & 0.182 & 1.471 & 131.16 & 0.997 \\
\hline $7000-12500$ & 0.316 & 0.127 & 1.586 & 275.88 & 0.998 \\
\hline 125000 & 0.341 & 0.102 & 1.713 & 398.77 & 0.999 \\
\hline
\end{tabular}

$K_{\text {sat }}$ and $\alpha$ parameters are represented as geometric mean. Other parameters are arithmetic mean $(N=3$ replicates). 
lowest $K_{\text {sat }}$ estimated for intercanopy areas was about $28 \mathrm{~cm} \mathrm{~d}^{-1}$, still high enough to allow water entry for most storms likely to be experienced in the area (Miller and Gustafson, 1996).

\section{Discussion and conclusions}

The interrelated biotic and abiotic processes that led to a mosaic of intercanopy and undercanopy areas, with water availability for plants strongly partitioned between these microenvironments, is the most important change over time between Site 1, the youngest, and Site 4, the oldest. The partitioning of water between intercanopy and undercanopy areas is best illustrated by the five-fold decrease in $K_{\text {sat }}$ in intercanopy areas from the youngest (Site 1) to the oldest site (Site 4) (see Fig. 5). The trend of $K_{\text {sat }}$ reduction in intercanopy areas is similar to findings by Young et al. (2004) in the Providence Mountains of the Mojave National Preserve, except that the latter exhibited a larger degree of $K_{\text {sat }}$ reduction (100-fold). With intercanopy areas representing between 69 and 96 percent (Table 1) of the four sites based on mean live plant cover, processes affecting and leading to the development and maintenance of this microenvironment play a dominant role in determining and maintaining landscape features. If a single element were to be singled out as driving this process, it would be the aeolian deposition and accumulation of fines, leading to the development of Av horizons in the intercanopy areas that reduced $K_{\text {sat }}$ and water infiltration. Yucca Playa, upwind of the sites during nearly half of the year, and other playas in the region would be sources of aeolian material (Pelletier and Cook, 2005). In short, the sites studied herein suggest that physical processes may be more dominant in

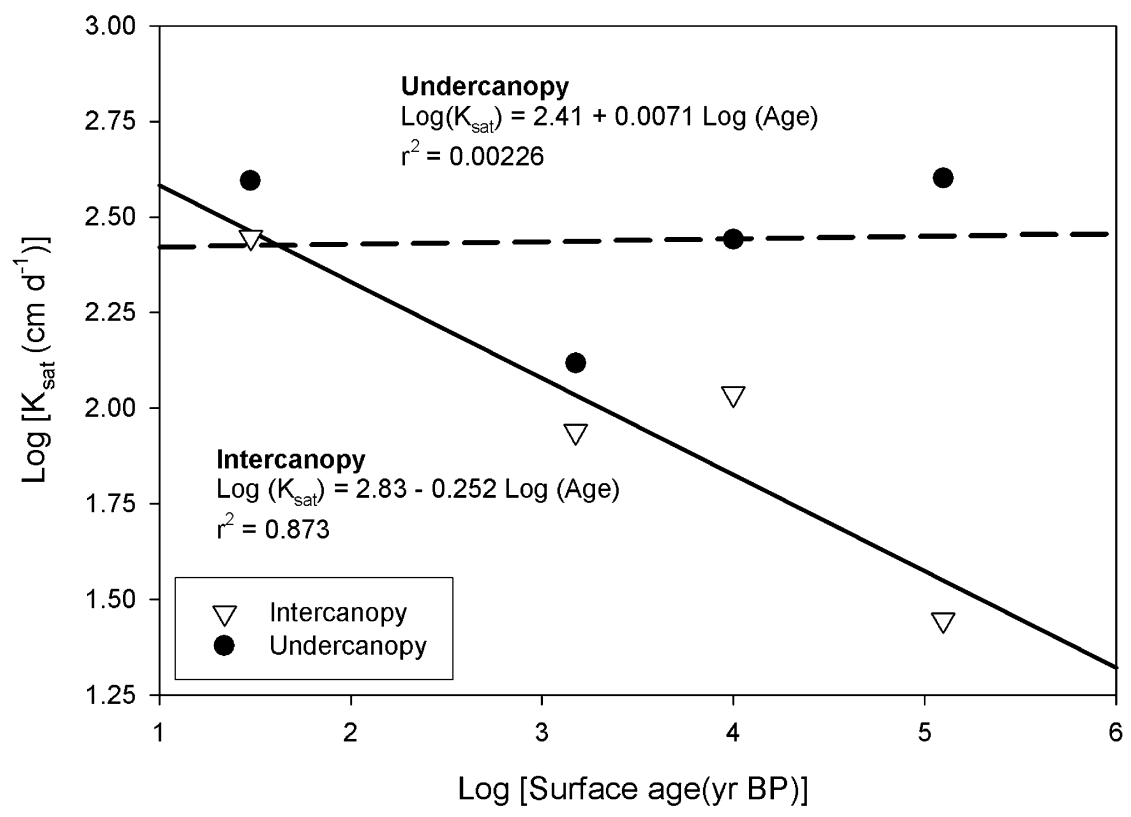

Fig. 5. Geometric means of $K_{\text {sat }}$ for intercanopy and undercanopy areas as a function of time for four surfaces of different age in the northern Mojave Desert. Regression models are shown as solid lines. 
conditioning biological processes over longer timeframes in the evolving landscape mosaic in the northern Mojave Desert. Other researchers have made similar findings (cf. Hamerlynck et al., 2002) in this region, and in other semi-arid sites (Eagleson, 2002).

However, time alone does not entirely explain the development of important features, such as the Av soil horizons, that affect water partitioning. Modern dust accumulation rates such as measured by Reheis et al. (1995) in southern California and Nevada could be sufficient for the development of incipient Av horizons such as at Site 2. In addition, because the NTS was the principal location of nuclear testing (atmospheric and underground) by the US until 1992 (US Department of Energy (DOE), 2000), completely ruling out the addition of small amounts of aeolian deposition from testing is not possible. However, rather than representing incremental increases in fines over time, major Av soil horizons such as those at Site 3 as well as possibly at Site 4 probably relate to environmental response to climate change at the late Pleistocene-Holocene transition. Full-glacial climate reconstructions for the northern Mojave Desert include an annual temperature decrease of $6{ }^{\circ} \mathrm{C}$ and a 40 percent increase in effective precipitation (Spaulding, 1985). With the transition to the Holocene, dust pulses throughout the region due to desiccation of pluvial lakes (Benson et al., 1990) and reduced vegetation cover (Spaulding, 1985; Van Devender et al., 1987) led to large quantities of clay and silt deposition throughout the region (e.g., Wells et al., 1987). Consequently, development of features such as thick Av horizons is not simply a consequence of time, but whether a particular event, such as a major climate transition, occurred during a particular period of time that a surface existed.

There is now general agreement that the formation of Av horizons is a result of aeolian silt and clay deposition, infiltration, and accumulation beneath surface stones, with the surface clasts initially contributing to surface roughness that promotes deposition, but also resulting in co-development of desert pavements (e.g., McDonald et al., 1996; McFadden et al., 1998). Although desert pavement clasts were removed when TI tests were conducted at Sites 3 and 4, the presence of clasts in addition to the Av horizon would likely further reduce infiltration in the intercanopy areas. Desert pavement development at the sites examined herein was associated with decreasing percent cover by perennial plants and annuals, with density of annuals in intercanopy areas decreasing sooner and in higher percentages than perennials. Compared to Site 2, moderate pavement development in intercanopy areas on Site 3 correlates with a 73 percent decrease in annual density, while at Site 4; the oldest site where the desert pavement was best developed, annual density was 94 percent less than that at Site 2. Although perennial cover was higher at Site 3 than the two younger sites, the percent cover at Site 4, was 8 percent lower than at Site 3 . Similar relationships between plant cover and desert pavement development have been documented elsewhere in the southwestern US including the Yuma Proving Ground in Arizona and the Providence Mountains in California (McAuliffe and McDonald, 2006; McDonald et al., 2003).

On surfaces older than the Pleistocene-Holocene transition, such as Site 4, the time of formation of Av horizons and desert pavements is debatable. For example, Quade (2001) notes that desert pavements in the Amargosa Valley, immediately south of the NTS, are not found above the zone of C. ramossisma, the dominant shrub at Site 4. Assuming a similar relationship between vegetation zones as today, Quade (2001) postulates that the downward displacement of plant communities during the last full glacial by $1000-1400 \mathrm{~m}$ elevation (Spaulding, 1990) would have eliminated all desert pavements in Yucca Flat and 
other mid- and higher-elevation basins in the region. If true, then the desert pavement and Av horizons at Site 4 may have reformed after approximately $15000 \mathrm{yr}$ BP during the Pleistocene-Holocene transition. In contrast, McFadden et al. (1998) postulate that even during glacial periods, the water-balance features of intercanopy areas may have limited vegetation establishment, allowing partial preservation of Av horizons at older sites, at least at elevations below about $800 \mathrm{~m}$.

Although abiotic processes may become dominant over time, each site provides evidence that both biotic processes have influenced landscape development as well. For example, the correlation between the density of animal burrows and perennial shrubs on the sites is evidence that burrowing activity plays a significant role in the development and maintenance of fertile island shrubs (Bolling and Walker, 2002), although from year to year, the absolute number of small mammals correlates strongly with the amount of winter precipitation (Beatley, 1969). Factors and processes that helped to perpetuate fertile islands and mounds across the timescale represented by the study sites have probably included animal burrowing that disrupted soil horizon development, maintaining higher $K_{\mathrm{sat}}$ in undercanopies and promoting deeper percolation of water. At Site 2, after only 1000-3000 years of site evolution, the density of native annuals was similar in the undercanopy and the intercanopy areas (Fig. 3). However, the density of burrows was approximately twice as high in the undercanopy as the intercanopy, although the difference was not statistically significant at $\alpha=0.05$. If soil bulk density in the undercanopy is lower, it may require less energy for burrowing by animals, and result in greater water infiltration and soil water retention, critical to perennial shrub survival in arid environments. It is also likely that these intercanopy sites experience greater cycling and concentrations of soil nutrients, particularly nitrogen and phosphorus, elements generally considered most limiting to plant growth in arid regions (Schlesinger et al., 1996; Whitford and Kay, 1999).

However, differences in the absolute percent cover (annuals, perennials, and total) measured in this study should best be viewed as relative rather than absolute values. Recurring wet and dry cycles at different time scales result in episodic opportunities for successful natural recruitment of many plant species in this region (McAuliffe and McDonald, 2006; Webb et al., 1988). Over a 12-year period, Beatley (1980) measured 14 percent death and 20-30 percent recruitment by seedlings or vegetation propagation because of fluctuations in the timing and total precipitation in the northern Mojave-Great Basin transition region in Nevada. However, just as significant was that Beatley (1980) noted that plants recruited to the sites following diebacks tended to be the same as those previously present, suggesting that abiotic features such as the degree of soil development, and the edaphic properties of plant species, strongly influenced reestablishment of individual plants. Wallace and Romney (1972) and Wallace et al. (1980) hinted at similar links between soils and plants species, partitioning surface soils into highly productive (i.e., fertile islands or undercanopies) and poorly productive areas (intercanopies) that were important for maintaining Mojave Desert ecosystems.

Nevertheless, biological activity has impacted soil forming processes and resulting soil hydrology over time. For example, while $K_{\text {sat }}$ decreased from the youngest to the oldest site, little change was observed in undercanopy $K_{\text {sat }}$. A combination of factors may contribute to this including bioturbation of near-surface soil (and particularly the disruption of the Av horizon), rooting by perennial plants that created micropores, and deposition of wind-suspended particles due to surface roughness created by the shrubs. The general trend of higher percentages of fine particles with site age (Table 4 ) is consistent 
with Caldwell et al. (2006) for soils at the Fort Irwin National Training Center in the western Mojave Desert (Fig. 5).

If only the percent cover of perennial vegetation is examined, the relationship of soil morphology and hydrology, and biological activity distribution, could be underestimated. For example, for the four sites in this study, perennial vegetation was highest (31 percent) on the 7000-12000-year-old site and 23 percent on Site 4, the oldest site. More compelling is the change in winter annual density. It was highest on Site 2 ( 246 plants $\left./ \mathrm{m}^{2}\right)$, with comparable densities in undercanopy and intercanopy microsites. In contrast, at Site 4 , the oldest site, annual diversity was less than 1 species $/ \mathrm{m}^{2}$ and density was 4 plants $/ \mathrm{m}^{2}$ at Site 4 . In terms of soil water balance on the landscape scale, winter annual populations are likely to influence potential ET from only the top $20-30 \mathrm{~cm}$ of soil and for just 3-5 months of the year (Young et al., 2006). Further, heavier-textured soil horizons (i.e., those with higher proportions of silt and clay) have increased water-holding capacities, keeping water closer to the ground surface and available for evaporation (Hillel, 1998; Hillel and van Bavel, 1976), and reducing the depth of percolation for a given precipitation event. These feedback mechanisms may further aid the persistence of intercanopy areas.

For both floral and faunal activity, intercanopy areas likely impose greater abiotic stress because of their higher irradiance and surface temperatures, lower nutrient availability, and, consistent with results of this study, reduced water infiltration (Housman et al., 2003). In contrast, micro- and macrofauna are attracted to the undercanopy of dominant shrubs as locales of lower daytime temperatures and the more abundant food sources. However, observations during this study indicated faunal activity contributed to plant recruitment in the intercanopy areas at Site 1, illustrating the role of bioturbation in establishment of vegetation on newly created surfaces. Foraging by small mammals observed in October 2002 created active burrows as far as $3.9 \mathrm{~m}$ from mature E. nevadensis shrubs. During flora surveys in June 2003, many of these same burrows had collapsed, creating depressions 7-9 cm wide and 4-5 cm deep in which individuals of Stephanomeria pauciflora and various Astragalus sp. had germinated. Focused water infiltration, seed caches deposited by the animals, and leaf-letter, animal feces, and tissue deposition are all processes that could contribute to plant establishment in the burrowed sites in undercanopy areas as well as intercanopy areas (Wallace et al., 1980).

Trends in winter annual density and diversity were similar to the distribution and density of burrows in undercanopy and intercanopy areas (Fig. 3). However, at the older sites (3 and 4), the difference in burrow density between intercanopy and undercanopy microsites was not statistically significant. This may suggest a limitation in the use of the number of active burrows as a measure of small mammal abundance and activity. As noted in the soil morphology descriptions, burrowing contributed to mounds of finergrained material in the undercanopy of shrubs, particularly at Sites 2 and 3. However, if bioturbation is active, previously formed burrows are quickly destroyed by new ones, such that the actual number of open burrows at any one time may underrepresent the abundance of small animals.

\section{Acknowledgements}

Thanks are extended to Susan Edwards and Robert Jones of the Desert Research Institute (DRI) for assistance in researching the history of sites and interpreting archeological material at Site 3. Mary Cablk of DRI provided insight on burrowing 
characteristics of animals. Julianne Miller, David Gillespie, John Goreham, and Darren Meadows assisted with fieldwork. Stuart Rawlinson of National Security Technologies assisted with selection of study sites. The Waste Management Program, US Department of Energy (DOE), National Nuclear Security Administration Nevada Site Office and DOE Environmental Management Science and Technology Development provided funding under Contract No. DE-AC52-00NV13609.

\section{References}

Ankeny, M.D., Kaspar, T.C., Horton, R., 1988. Design for an automated tension infiltrometer. Soil Science Society of America Journal 52, 893-896.

Beatley, J.C., 1969. Dependence of desert rodents on winter annuals and precipitation. Ecology 50, $721-724$.

Beatley, J.C., 1974. Phenological events and their environmental triggers in Mojave Desert ecosystems. Ecology $55,856-863$.

Beatley, J.C., 1975. Climates and vegetation pattern across the Mojave/Great Basin desert transition of southern Nevada. American Midland Naturalist 93, 53-70.

Beatley, J.C., 1980. Fluctuations and stability in climax shrub and woodland vegetation of the Mojave, Great Basin, and transitional deserts of southern Nevada. Israel Journal of Botany 28, 149-168.

Beck, D.A., Glancy, P.A., 2001. Flooding in the Amargosa River Drainage Basin, February 23-24, 1998, Southern Nevada and Eastern California, Including the Nevada Test Site. US Geological Survey Fact Sheet 036-01.

Benson, L.V., Currey, D.R., Dorn, R.I., Lajoie, K.R., Oviatt, C.G., Robinson, S.W., Smith, G.I., Stine, S., 1990. Chronology of expansion and contraction of four Great Basin lake systems during the past 35000 years. Palaeogeography, Palaeoclimatology, and Palaeoecology 78, 241-286.

Birkeland, P.W., 1999. Soils and Geomorphology. Oxford Press, New York.

Bolling, J.D., Walker, L.R., 2002. Fertile island development and perennial shrubs across a Mojave Desert chronosequence. Western North American Naturalist 6, 88-100.

Burt, W.H., Grossenheider, R.P., 1980. A Field Guide to the Mammals of North America North of Mexico. Houghton Mifflin Company, New York.

Caldwell, T.G., McDonald, E.V., Young, M.H., 2006. Soil disturbance and hydrologic response at the National Training Center, Ft. Irwin, California. Journal of Arid Environment 67, 456-472.

Casey, F.X.M., Derby, N.E., 2002. Improved design for an automated tension infiltrometer. Soil Science Society of America Journal 66, 64-67.

Crawley, D., Nickling, W.G., 2003. Drag partition for regularly-arrayed rough surfaces. Boundary-Layer Meteorology 107, 445-468.

Dreimanis, A., 1962. Quantitative gasometric determinations of calcite and dolomite by using Chittick apparatus. Journal of Sedimentary Petrology 32, 520-529.

Eagleson, P.S., 2002. Ecohydrology: Darwinian Expression of Vegetation Form and Function. Cambridge University Press, New York, NY.

Garner, W., Steinberger, Y., 1989. A proposed mechanism for the formation of 'fertile islands' in the desert ecosystem. Journal of Arid Environment 16, 257-262.

Gee, G.W., Or, D., 2002. Particle-size analysis. In: Dane, J.H., Topp, G.C. (Eds.), Methods of Soil Analysis. Physical Methods, Soil Science Society of America Book Series no. 5, Part 4, pp. 255-293.

Gillette, D.A., 1999. A qualitative geophysical explanation for "hot spot" dust emitting source regions. Contributions to Atmospheric Physics 72, 67-77.

Grayson, D.K., 1993. The Desert's Past, A Natural Prehistory of the Great Basin. Smithsonian Institution Press, Washington, DC.

Green, R.A., Boone, J.L., Sowell, C.L., 1997. Abundance and species composition of rodent populations at Yucca Mountain, Nevada. US Department of Energy, Civilian Radioactive Waste Management System Management and Operation Contractor Report No. B-01717-5705-00034, CRWMS M\&O. ACC: MOL.19980123.0642, Las Vegas, NV, USA.

Greger, P., 1995. Status of horses, deer, and birds on the Nevada Test Site, 1994. In: Hunter, R.B. (Ed.), Status of the Flora and Fauna of the Nevada Test Site, 1994. DOE/NV/11432-195, UC-721. National Technical Information Service, US Department of Commerce, pp. 149-181. 
Hamerlynck, E.P., McAuliffe, J.R., McDonald, E.V., Smith, S.D., 2002. Impacts of desert soil processes and drought on contrasting Mojave Desert shrubs. Ecology 83, 768-779.

Hereford, R., Webb, R.H., Longpré, C.I., 2004. Precipitation history of the Mojave Desert region, 1893-2001: US Geological Survey Fact Sheet 117-03, 4pp.

Hickman, J.C., 1993. The Jepson Manual-Higher Plants of California. University of California Press, Berkeley. Hillel, D., 1998. Environmental Soil Physics. Academic Press, New York.

Hillel, D., van Bavel, C.H.M., 1976. Simulation of profile water storage as related to soil hydraulic properties. Soil Science Society of America Journal 40, 807-815.

Housman, D.C., Zitzer, S.F., Huxmans, T.E., Smith, S.D., 2003. Functional ecology of shrub seedling after a natural recruitment event and the Nevada Desert FACE Facility. Global Change Biology 9, 718-728.

Hunter, R.B., 1991. Bromus invasions on the Nevada Test Site: present status of B. rubens and B. tectorum with notes on their relationship to disturbance and altitude. Great Basin Naturalist 51, 176-182.

Hunter, R.B., Medica, P.A., 1987. Status of the flora and fauna of the Nevada Test Site, results of continuing basic environmental research January through December 1987. DOE/NV10630-2, Reynolds Electrical and Engineering Co., Inc., Las Vegas, NV, USA.

Jones, R.C., 2002. A class III cultural resources reconnaissance of the proposed underground test area ER-8-1 well pad and access road, Area 8, Yucca Flat, Nevada Test Site, Nye County, Nevada. Desert Research Institute Cultural Resource Reconnaissance Short Report No. SR012302-1, Project No. 020308. Las Vegas, NV, USA.

Machette, M.N., 1985. Calcic soils of the southwestern United States. Geological Society of America Special Paper, p. 203.

MacMahon, J.A., 1985. Deserts. National Audubon Society Nature Guides. Chanticleer Press, Inc., New York.

McAuliffe, J.R., McDonald, E.V., 2006. Holocene environmental change and vegetation contraction in the Sonoran Desert. Quaternary Research 65, 204-215.

McDonald, E.V., Pierson, F.B., Flerchinger, G.N., McFadden, L.D., 1996. Application of a process-based soil water balance model to evaluate the influence of late Quaternary climate change on soil-water movement in calcic soils. Geoderma 74, 167-192.

McDonald, E.V., McFadden, L.D., Wells, S.G., 2003. Regional response of alluvial fans to the PleistoceneHolocene transition and alluvial fan deposition in the Providence Mountains. In: Enzel, Y., Wells, S.G., Lancaster, N. (Eds.), Paleoenvironments and Paleohydrology of the Mojave and southern Great Basin deserts. Geological Society of America Special Paper 368, pp. 189-205.

McFadden, L.D., McDonald, E.V., Wells, S.G., Anderson, K., Quade, J., Forman, S.L., 1998. The vesicular layer of desert soils: genesis and relationship to climate change and desert pavements based on numerical modeling, carbonate translocation behavior, and stable isotope and optical dating studies. Geomorphology $24,101-145$.

Miller, J.J., Gustafson, D.L., 1996. Flood Assessment at the Area 3 Radioactive Waste Management Site, DOE/ Nevada Test Site, Nye County, Nevada: Las Vegas, NV, Raytheon Services Nevada.

Mohanty, B.P., Mousli, Z., 2000. Saturated hydraulic conductivity and soil water retention properties across a soil-slope transition. Water Resources Research 36, 3311-3324.

Mualem, Y., 1976. A new model for predicting the hydraulic conductivity of unsaturated porous media. Water Resources Research 12, 513-522.

Ostler, K.W., Hansen, D.J., Anderson, D.C., Hall, D.B., 2000. Classification of vegetation on the Nevada Test Site, Bechtel Nevada Ecological Services, Report No. DOE/NV/11718-477.

Pelletier, J.D., Cook, J.P., 2005. Deposition of windblown playa dust over geologic time scales. Geology 33, 909-912.

Quade, J., 2001. Desert pavements and associated rock varnish in the Mojave Desert: how old can they be? Geology 29, 855-858.

Reheis, M.C., Goodmacher, J.C., Harden, J.W., McFadden, L.D., Rockwell, T.K., Shroba, R.R., Sowers, J.M., Taylor, E.M., 1995. Quaternary soils and dust deposition in southern Nevada and California. Geological Society of America Bulletin 107, 1003-1022.

Reynolds, W.D., Elrick, D.E., 1991. Determination of hydraulic conductivity using a tension infiltrometer. Soil Science Society of America Journal 55, 633-639.

Rhoades, J.D., 1996. Salinity: electrical conductivity and total dissolved solids. In: Sparks, D.L. (Ed.), Methods of Soil Analysis, Part 3: Chemical Methods Monograph No. 5. American Society of Agronomy, pp. 417-435.

Rickard, W.H., Beatley, J.C., 1965. Canopy-coverage of the desert shrub vegetation mosaic of the Nevada Test Site. Ecology 46, 524-529. 
Rostagno, C.M., 1989. Infiltration and sediment production as affected by soil surface conditions in a shrubland of Patagonia, Argentina. Journal of Range Management 42, 382-385.

SAS, 2005. Statistical Analysis System ${ }^{\circledR}$, Version 9.1.3, Cary, NC, USA.

Schlesinger, W.H., Raikes, J.A., Hartley, A.E., Cross, A.F., 1996. On the spatial pattern of soil nutrients in desert ecosystems. Ecology 77, 364-374.

Shafer, D.S., Young, M.H., Zitzer, S.F., McDonald, E.V., Caldwell, T., 2004. Coupled environmental processes and long-term performance of landfill covers in the Northern Mojave Desert. Desert Research Institute Publication No. 45203 for the US Department of Energy, Nevada Site Office, Las Vegas, NV, USA.

Simunek, J., Sejna, M., van Genuchten, M.T., 1996. The HYDRUS-2D software package for simulating water flow and solute transport in two-dimensional variably saturated media. Version 1.0. IGWMC-TPS-53, International Ground Water Modeling Center, Colorado School of Mines, Golden, CO, USA.

Spaulding, W.G., 1985. Vegetation and climates of the last 45000 years in the vicinity of the Nevada Test Site, South-Central Nevada. US Geological Survey Professional Paper 1329.

Spaulding, W.G., 1990. Vegetational and climatic development of the Mojave Desert: the last glacial maximum to the present. In: Betancourt, J.L., Van Devender, T.R., Martin, P.S. (Eds.), Packrat Middens, the Last 40000 Years of Biotic Change, pp. 166-199.

Swadley, W.C., Hoover, D.L., 1990. Geologic map of the surficial deposits of the Yucca Flat area, Nye County, Nevada. US Geological Survey Miscellaneous Investigation Series Map I-2047, scale 1:48 000.

US Department of Agriculture (USDA), 1999. Examination and description of soils in the field. In: Soil Survey Manual, USDA-Agriculture Research Service. US Government Printing Office, Washington, DC.

US Department of Energy (DOE). 2000. United States Nuclear Tests, July 1945 through September 1992, DOE/ NV-209, Revision 15.

Van Devender, T.R., Thompson, R.S., Betancourt, J.L., 1987. Vegetation history of the deserts of the southwestern North America: the nature and timing of the late Wisconsin-Holocene transition. In: Ruddiman, W.F., Wright, Jr., H.E. (Eds.), North America and Adjacent Oceans during the Last Deglaciation. Geological Society of America, K-3, Boulder, CO, USA, pp. 323-352.

van Genuchten, M.T., 1980. A closed-form equation for predicting the hydraulic conductivity of unsaturated soils. Soil Science Society of America 44, 892-898.

Wallace, R.B., Romney, E.M., 1972. Radioecology and ecophysiology of desert plants at the Nevada Test Site. National Technical Information Service, US Atomic Energy Commission Report TID-25954.

Wallace, R.B., Romney, E.M., Hunter, R.B., 1980. The challenge of a desert: revegetation of disturbed desert lands. Great Basin Naturalist Memoirs 4, 216-225.

Warren, C.N., Crabtree, R.H., 1986. Prehistory of the Southwestern Area. In: D'Azevedo, W.L. (Ed.), Handbook of North American Indians, vol. 11. Great Basin. Smithsonian Institution, Washington, DC, pp. 183-193.

Webb, R.H., 2002. Recovery of severely compacted soils in the Mojave Desert, California, USA. Arid Land Research and Management 16, 291-305.

Webb, R.H., Steiger, J.W., Newman, E.B., 1988. The response of vegetation to disturbance in Death Valley National Monument, California. US Geological Survey Bulletin 1793.

Wells, S.G., McFadden, L.D., Dohrenwend, J.C., 1987. Influence of late Quaternary climatic changes on geomorphic and pedogenic processes on a desert piedmont, eastern Mojave Desert, California. Quaternary Research 27, 130-146.

West, N.E., 1983. Colorado Plateau-Mohavian blackbrush semi-desert. In: West, N.E. (Ed.), Temperate Deserts and Semi-Deserts. Elsevier Scientific Publishing, Amsterdam, pp. 399-411.

White, I., Sully, M.J., 1992. On the variability and use of the hydraulic conductivity alpha parameter in stochastic treatments of unsaturated flow. Water Resources Research 28, 209-213.

Whitford, W.G., Kay, F.R., 1999. Biopedturbation by mammals in deserts: a review. Journal of Arid Environment 41, 203-230.

Young, M.H., McDonald, E.V., Caldwell, T.G., Benner, S.G., Meadows, D.G., 2004. Hydraulic properties of a desert soil chronosequence in the Mojave Desert, USA. Vadose Zone Journal 3, 956-963.

Young, M.H., Albright, W., Pohlmann, K.F., Pohll, G., Zachritz, W.H., Zitzer, S., Shafer, D.S., Nester, I., Oyelowo, L., 2006. Incorporating parametric uncertainty in the design of alternative landfill covers in arid regions. Vadose Zone Journal 5, 742-750.

Zitzer, S.F, Shafer, D.S., Young, M.H., McDonald, E.V., Caldwell, T., Goreham, J., 2004. Changes in diversity and density of northern Mojave plant communities resulting from desert pavement development on a 125000 year-old chronosequence. Ecological Society of America, 20, 2004 Annual Meeting, Portland, OR, USA. 